\title{
PENGARUH KADAR AIR PALM SUGAR (GULA SEMUT) SEBAGAI FAKTOR PENGENDALIAN KUALITAS PADA CV. DWI SARANA MANDIRI DENGAN MENGGUNAKAN METODE SEVEN TOOLS
}

\author{
Nova Wisnianingsih' ${ }^{1)}$, Estiningsih' ${ }^{2)}$, Sewaka $^{2)}$ \\ ${ }^{1)}$ Mahasiswi Program Studi Teknik Industri, Universitas Pamulang \\ ${ }^{2)}$ Dosen Fakultas Teknik Program Studi Teknik Industri, Universitas Pamulang \\ dosen00311@unpam.ac.id
}

\begin{abstract}
ABSTRAK
Departemen Quality Control diharapkan melakukan surveilans terhadap pengaruh statistik yang disebabkan oleh kelembaban. Metodenya Yang digunakan dalam penelitian ini adalah Statistical Process Control (SPC) adalah metode yang digunakan untuk mengukur tingkat kontrol kualitas dan tingkat kerusakan yang terjadi di Proses produksi sudah selesai. Dari data histogram pada bulan Mei - Oktober 2012 untuk melihat pengaruh kerusakan yang terjadi, disebabkan oleh kadar air yang tinggi dan Kandungan air yang rendah mencapai $5.080 \mathrm{~kg}$ dengan total produksi 41.810, tercapai 12,15\%. Diagram pareto mengklarifikasi kerusakan oleh kelembaban membuat faktor utama yang harus dialamatkan di CV mandiri. Dwi Sarana Mandiri. Diantara Kerusakan yang disebabkan oleh kadar air yang tinggi dan kadar air yang rendah memiliki kekuatan yang kuat Hubungan dengan hasil produksi yang didapat, hal ini ditunjukkan dengan sebaran Diagram tegak lurus dan sedikit condong ke kanan. Kerusakan air tinggi Tingkat dan kadar air yang rendah sangat mempengaruhi hasil produksi dengan beberapa titik yang melintasi garis kontrol (BKB) digambarkan dalam diagram c kontrol cacat (Atribut). Hasil penelitian dari kerusakan oleh kelembaban adalah karena faktor manusia, mesin, metode, material, dan pengukuran lingkungan.
\end{abstract}

Kata Kunci : Kadar air, Palm Sugar, Seven Tools, Kualitas

\section{PENDAHULUAN}

Kualitas suatu produk adalah hal yang sangat diperhatikan oleh pelanggan. Untuk mencapai kualitas yang diharapkan banyak cara yang dapat dilakukan salah satunya dengan cara statistik dengan menggunakan metode seven tools. Statistik adalah seni pengambilan keputusan tentang suatu proses berdasarkan suatu analisis informasi yang terkandung didalam suatu sampel.

Metode statistik memainkan peranan penting dalam jaminan kualitas. Metode statistik itu memberikan cara-cara pokok dalam pengambilan sampel produk, pengujian serta evaluasinya dan informasi didalam data itu digunakan untuk mengendalikan dan meningkatkan proses pembuatan. Lagipula statistik adalah bahasa yang digunakan oleh insinyur pengembangan, pembuatan, pengusahaan, manajemen, dan komponen- komponen fungsional bisnis yang lain untuk berkomunikasi tentang kualitas. Untuk menjamin proses produksi dalam kondisi baik dan stabil atau produk yang dihasilkan selalu dalam daerah standar, perlu dilakukan pemeriksaan terhadap titik origin dan hal-hal yang berhubungan, dalam rangka menjaga dan memperbaiki kualitas produk sesuai dengan harapan. Hal ini disebut Statistical Process Control (SPC). Dalam pengendalian proses statistik dikenal adanya "seven tools". Seven tools dari pengendalian proses statistik ini adalah metode grafik paling sederhana untuk menyelesaikan masalah. Seven tools tersebut adalah Flowchart, Check sheet (lembar pemeriksaan), Histogram, Diagram pareto, Diagram kontrol, Diagram Scatter dan Diagram sebab akibat. Setiap hasil produksi akan diawasi dengan cara statistik melalui pemeriksaan sampel pada kegiatan pengawasan 
kualitas suatu produk. Produk yang diawasi disini adalah Palm Sugar (gula semut), palm sugar diproduksi di CV. Dwi Sarana Mandiri dengan menerapkan sistem pengendalian kualitas terhadap setiap proses produksi palm sugar.

Palm sugar atau gula semut adalah gula jawa atau gula aren yang diolah menjadi bentuk butiran-butiran kristal dengan kadar air yang bagus yaitu kering. Dalam proses produksi palm sugar hal yang sangat diperhatikan adalah kebersihan dan kadar air. Palm sugar berasal dari bahan alam yaitu nira aren mentah yang kemudian dimasak dan diolah menjadi bahan baku palm sugar. Pemasakan dilakukan dengan memanaskan langsung nira aren dengan tungku api yang berasal dari kayu bakar, kemudian diaduk hingga bewarna coklat dan matang. Palm sugar akan sangat bagus kualitasnya jika kadar airnya sesuai dengan standar. Pengaruh yang diberikan oleh kadar air sangat banyak baik pada bahan baku, bahan setengah jadi dan produk jadi. Jika kadar air tinggi maka gula ini akan basah dan lengket, dalam proses pengeringan akan membutuhkan waktu yang lama pula, namun jika kadar air sesuai maka gula ini kulitasnya baik dan aromanya harum gula aren yang sering disebut gula merah atau gula jawa. Maka dari itu departement Quality Control diharapkan melakukan pengawasan secara statistik terhadap pengaruh yang ditimbulkan oleh kadar air. Dalam setiap perusahaan manufacturing banyak sekali halhal yang harus diperhatikan antara lain, proses produksi, bahan baku, penerimaan barang, pengiriman barang dan lain-lain sebagainya. Dalam hal ini kualitas sangat penting untuk menentukan perusahaan tersebut akan diminati, disukai dan dibeli oleh para konsumennya. Produk yang diproduksi oleh suatu perusahaan tidak hanya memproduksi tetapi banyak hal yang akan dipertimbangkan dan salah satunya adalah analisa pengendalian kualitas proses produksi. CV. Dwi Sarana Mandiri (DSM) merupakan perusahaan persekutuan komanditer yang bergerak dibidang agroindustri. CV. Dwi Sarana Mandiri memberikan produk-produk olahan yang berasal dari alam. Hanya produk berkualitas yang layak untuk didistribusikan hingga sampai ke tangan konsumen. Meningkatnya penjualan dan semakin banyaknya macam produk yang diproduksi oleh perusahaan ini menjadikan CV. Dwi Sarana Mandiri termasuk dalam kategori perusahaan berkembang. Yang sangat mementingkan kualitas palm sugar, banyak kerugian yang akan dihadapi jika kadar air palm sugar tidak masuk standar yang telah ditetapkan. Palm sugar yang dihasilkan oleh CV. Dwi Sarana Mandiri sebagian besar dijadikan bahan baku utama maupun bahan baku tambahan bagi produk-produk olahan yang dihasilkan oleh perusahaan lain, oleh sebab itu kadar air sangat mempengaruhi palm sugar. Konsumen akan menolak jika kadar air palm sugar tinggi yang menyebabkan palm sugar menjadi lengket dan membeku sehingga kesulitan dalam penggunaannya.

Kualitas yang baik akan memberikan kepuasan tersendiri kepada pelanggan dan akan meningkatkan keuntungan pada sebuah perusahaan. Pelanggan akan mencari produk yang berkualitas tinggi dan sesuai dengan selera yang diinginkan. Oleh sebab itu perusahaan CV. Dwi Sarana Mandiri sangat memperhatikan kadar air palm sugar dan terus menerus meningkatkan kualitas palm sugar.

\section{LANDASAN TEORI}

Tahap ini merupakan tahap awal dari metode penelitian dimana pada tahap ini dilakukan studi lapangan yang digunakan untuk mengetahui hal-hal yang perlu diamati dan masalah yang terjadi di perusahaan. Dengan melakukan studi ini diharapkan, penulis memperoleh data-data dan informasi yang dibutuhkan untuk tahap-tahap berikutnya serta memperoleh gambaran perusahaan secara keseluruhan. . Studi Lapangan pada tahap ini dilakukan pengamatan permasalahan yang ada pada Pengaruh Kadar Air (Moisture) Palm Sugar sebagai Faktor Pengendalian Kualitas Pada CV. Dwi Sarana Mandiri dengan cara pengamatan langsung di perusahaan, mewawancarai dan melakukan tanya jawab kepada orang-orang yang memiliki keterikatan dengan permasalah yang akan diteliti pada perusahaan tersebut. Studi Pustaka,Pada tahap ini, berhubungan dengan masalah yang akan 


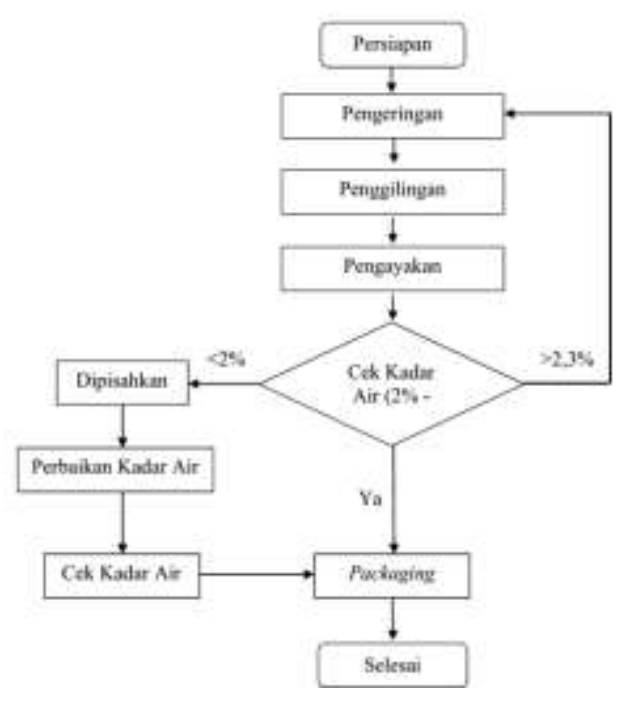

\section{METODOLOGI PENELITIAN}

Flowchart atau diagram alir secara grafis menunjukkan sebuah proses atau sistem dengan menggunakan kotak dan garis yang saling

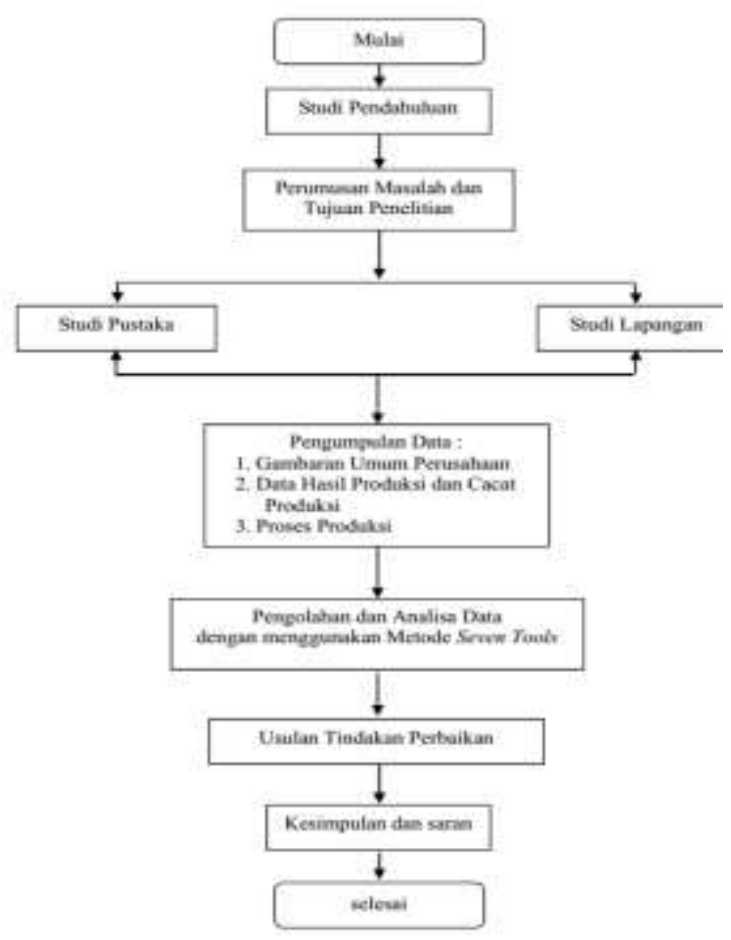

dibahas dan digunakan dalam memecahkan masalah serta mengatasi solusi untuk mengatasi masalah tersebut. Pengolahan data dilakukan berdasarkan teori-teori yang didapat pada bukubuku dan jurnal menjadi referensi. Data diambil dari hasil produksi dan hasil cacat yang dihasilkan dalam setiap produksi. Pengumpulan data ini dilakukan untuk memperoleh data-data yang diperlukan dalam penelitian ini. Data-data dan informasi yang dikumpulkan untuk menunjang pengolahan data adalah sebagai berikut:Setelah data-data terkumpul, maka selanjutnya dilakukan pengolahan dan analisa data dengan cara Statistical Process Control (SPC)

berhubungan. Diagram ini cukup sederhana, tetapi merupakan alat yang sangat baik untuk mencoba memahami sebuah proses atau menjelaskan langkah-langkah sebuah proses. Alur proses produksi Palm Sugar CV. Dwi Sarana Mandiri dapat dilihat pada Gambar 4.6.

\section{HASIL DAN PEMBAHASAN}

Lembar pemeriksaan merupakan alat pengumpul dan penganalisis data yang disajikan dalam bentuk tabel yang berisi data jumlah barang yang diproduksi dan jenis ketidaksesuaian beserta dengan jumlah yang dihasilkannya. Pelaksanaannya dilakukan dengan cara mencatat banyaknya muncul karakteristik kerusakan suatu produk yang berpengaruh terhadap kualitasnya. CV. Dwi Sarana Mandiri melakukan produksi berdasarkan pesanan pembelian (Purchasing Order), hingga produksi tidak selalu rutin dan juga tidak tertutup kemungkinan untuk tidak produksi sama sekali.Check Sheet masalah yang sering terjadi pada kualitas palm sugar pada enam bulan terakhir yaitu bulan Mei 2012 - Oktober 2012 dapat dilihat pada Tabel 1 


\begin{tabular}{|c|c|c|c|c|c|c|c|c|}
\hline Bulan & $\begin{array}{c}\text { Total } \\
\text { Produksi }\end{array}$ & $\begin{array}{c}\text { Reject Kadar } \\
\text { Air Tinggi }\end{array}$ & $\begin{array}{c}\text { Reject Kadar } \\
\text { Air Rendah }\end{array}$ & $\begin{array}{c}\text { Reject } \\
\text { Ukuran Partikel }\end{array}$ & $\begin{array}{c}\text { Reject } \\
\text { Kebersinan }\end{array}$ & $\begin{array}{c}\text { Total } \\
\text { Reject }\end{array}$ & $\begin{array}{c}\text { Persen } \\
(\%)\end{array}$ & Ket. \\
\hline Mei & 9320 & 520 & 590 & 60 & 30 & 1200 & 12,88 & \\
\hline Juni & 1380 & 100 & 110 & 10 & 10 & 230 & 16,67 & \\
\hline Juli & 0 & 0 & 0 & 0 & 0 & 0 & 0,00 & Tidak ada Produksi \\
\hline Agustus & 4940 & 460 & 190 & 10 & 30 & 690 & 13,97 & \\
\hline September & 10500 & 670 & 450 & 70 & 50 & 1240 & 11,81 & \\
\hline Oktober & 15670 & 1000 & 990 & 40 & 40 & 2070 & 13,21 & \\
\hline Total & 41810 & 2750 & 2330 & 190 & 160 & 5430 & 12,99 & \\
\hline
\end{tabular}

\section{A. Histogram}

Dari data check sheet yang telah ada dapat dilihat kerusakan produk palm sugar yang terjadi di CV. Dwi Sarana Mandiri, selain oleh pengaruh kadar air, juga terdapat beberapa pengaruh lain yaitu ukuran partikel gula dan kebersihan gula tersebut. Maka selanjutnya untuk lebih jelasnya data akan disajikan dalam bentuk histogram, untuk memudahkan kita dalam melihat pengaruh yang telah disebabkan oleh kadar air, ukuran partikel dan kebersihan sehingga menimbulkan kerusakan produk. Dari histogram dapat diketahui bahwa kerusakan atau kecacatan produk lebih banyak terjadi disebabkan oleh kadar air gula yang tinggi (jenis reject 1) dan kadar air gula yang rendah (jenis reject 2) dengan kerusakan karena kadar air yang tinggi hingga mencapai $2750 \mathrm{~kg}$ dan oleh kadar air yang rendah sebanyak $2330 \mathrm{~kg}$ sedangkan oleh ukuran partikel (jenis reject 3) adalah $190 \mathrm{~kg}$ dan kerusakan kebersihan (jenis reject 4) adalah $160 \mathrm{~kg}$, dihitung dari keseluruhan hasil kerusakan selama enam bulan. Sedangkan ukuran partikel dan kebersihan tidak mencapai angka kerusakan yang tinggi. Jadi, terlihat jelas bahwa kadar air tinggi dan rendah (jenis reject 1 dan 2) akan sangat mempengaruhi produk palm sugar (gula semut) sehingga menjadi faktor utama dalam pengendalian kualitas di CV. Dwi Sarana Mandiri.

\section{B. Diagram Pareto}

Setelah melihat data dari histogram maka untuk lebih memperjelas kerusakan yang dominan, maka dilakukan analisa dengan diagram pareto.
Diagram pareto adalah grafik balok dan grafik baris yang menggambarkan perbandingan masing-masing jenis data terhadap keseluruhan. Dengan memakai diagram pareto, dapat terlihat masalah mana yang dominan sehingga dapat mengetahui prioritas penyelesaian masalah. Fungsi Diagram pareto adalah untuk mengidentifikasi atau menyeleksi masalah utama untuk peningkatan kualitas dari yang paling besar ke yang paling kecil. Dari diagram pareto dapat jelas terlihat persoalan yang paling penting untuk ditangani. Pengaruh kadar air yang tidak sesuai yaitu kadar air tinggi dan kadar air yang rendah menjadikan kerusakan pada gula dengan persentase kerusakan pada bulan Mei 2012 dengan hasil produksi $9320 \mathrm{~kg}$, terdapat kerusakan sebanyak $1110 \mathrm{~kg}$ mencapai $11,90 \%$ yaitu dengan kerusakan yang disebabkan oleh kadar air tinggi sebanyak 5,57\% dan kerusakan oleh kadar air rendah sebanyak 6,33\%. Pada bulan Juni 2012 hasil produksi yang didapatkan adalah $1380 \mathrm{~kg}$, terdapat kerusakan oleh kadar air sebanyak $210 \mathrm{~kg}$ mencapai $15,21 \%$ yaitu dengan kerusakan yang disebabkan oleh kadar air tinggi sebanyak 7,25\% dan kerusakan oleh kadar air rendah sebanyak 7,96\%. Pada bulan Agustus 2012 hasil produksi yang didapatkan adalah $4940 \mathrm{~kg}$, terdapat kerusakan oleh kadar air sebanyak $650 \mathrm{~kg}$ mencapai $13,15 \%$ yaitu dengan kerusakan yang disebabkan oleh kadar air tinggi sebanyak 9,31\% dan kerusakan oleh kadar air rendah sebanyak 3,84\%. Pada bulan September 2012 hasil produksi yang didapatkan adalah $10500 \mathrm{~kg}$, terdapat kerusakan oleh kadar air sebanyak $1120 \mathrm{~kg}$ mencapai $10,66 \%$ yaitu dengan kerusakan yang 
disebabkan oleh kadar air tinggi sebanyak 6,38\% dan kerusakan oleh kadar air rendah sebanyak 4,28\%. Pada bulan Oktober 2012 hasil produksi yang didapatkan adalah 15670 $\mathrm{kg}$, terdapat kerusakan oleh kadar air sebanyak $1990 \mathrm{~kg}$ mencapai $12,69 \%$ yaitu dengan kerusakan yang disebabkan oleh kadar air tinggi sebanyak $6,38 \%$ dan kerusakan oleh kadar air rendah sebanyak $6,31 \%$. Jadi, rata-rata kerusakan yang disebabkan oleh kadar air selama enam bulan penelitian di CV. Dwi Sarana Mandiri mencapai $12,15 \%$ yaitu dengan kerusakan oleh kadar air tinggi sebanyak 6,58\% dan kerusakan oleh kadar air rendah 5,57\%. Maka masalah yang paling penting yang harus diperhatikan menjadi lebih jelas. Karena pengaruh kadar air menyebabkan banyak terjadi kerusakan terhadap produk palm sugar.

\section{Scatter Diagram}

Untuk lebih mengetahui hubungan antara variabel kerusakan dengan variabel hasil produksi yang diperoleh, maka langkah selanjutnya adalah dengan menentukan kekuatan dan kelemahan hubungan variabel dengan menggunakan scatter diagram. Scatter diagram adalah grafik yang menampilkan hubungan antara dua variabel apakah hubungan antara dua variabel tersebut kuat atau tidak, yaitu antara faktor proses yang mempengaruhi proses dengan kualitas produk. Dari hasil scatter diagram,dapat diketahui bahwa hubungan antara kadar air yang tinggi dan kadar air yang rendah dengan hasil produksi berbanding lurus, semakin banyak hasil produksi yang diperoleh maka semakin banyak juga kerusakan yang disebabkan oleh kadar air yang tinggi. Diagram scatter di atas menggambarkan hubungan antara kedua variabel ini kuat yaitu maksimal positif karena garis lurus sedikit condong ke kanan. Dari hasil scatter diagram juga dapat diketahui bahwa hubungan antara kerusakan oleh ukuran partikel dan kebersihan dengan hasil produksi lemah, karena kerusakan yang terjadi tidak terlalu mempengaruhi hasil produksi, dapat dilihat pada diagram scatter hasil produksi yang banyak namun kerusakan sedikit.Dapat dilihat hubungan antara variabel di atas lemah karena tidak tegak lurus.

\section{Diagram Kontrol Cacat c (Atribut)}

Diagram cacat c (Atribut) untuk memperlihatkan banyaknya kecacatan yang terjadi dalam setiap bulan dan untuk mengetahui apakah kecacatan tersebut berada pada batas kendali. Dari diagram scatter di bawah ini masih ada kerusakan produk yang melewati batas kendali.

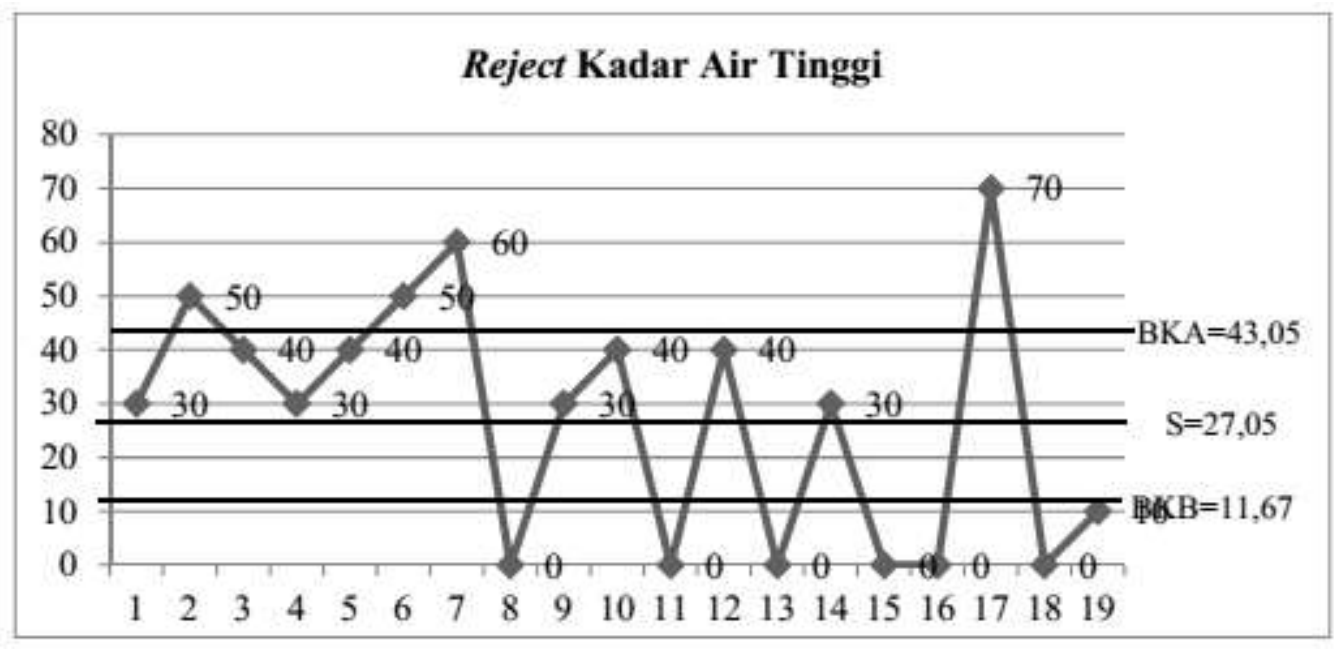

Gambar 1. Diagram Kontrol Cacat Kadar Air Tinggi Bulan Mei 2012 


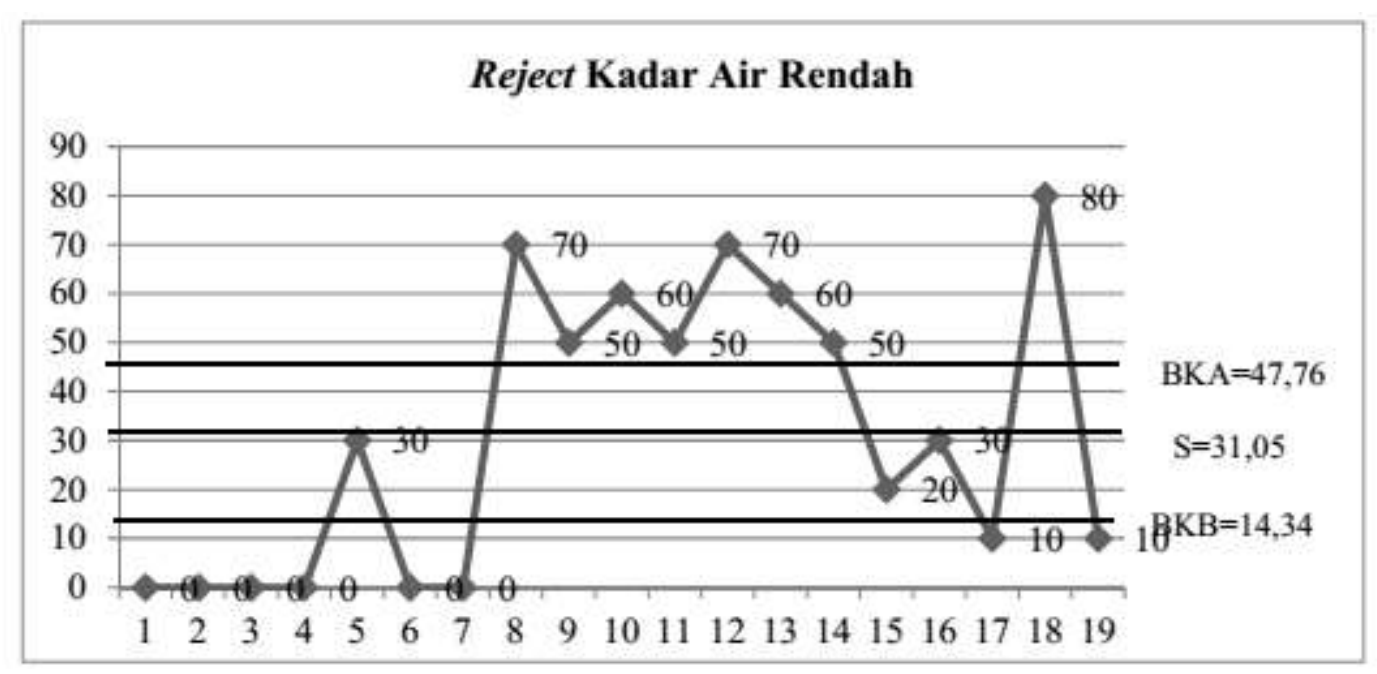

Gambar 2 Diagram Kontrol Cacat Kadar Air Rendah Bulan Mei 2012

7. Diagram Sebab Akibat

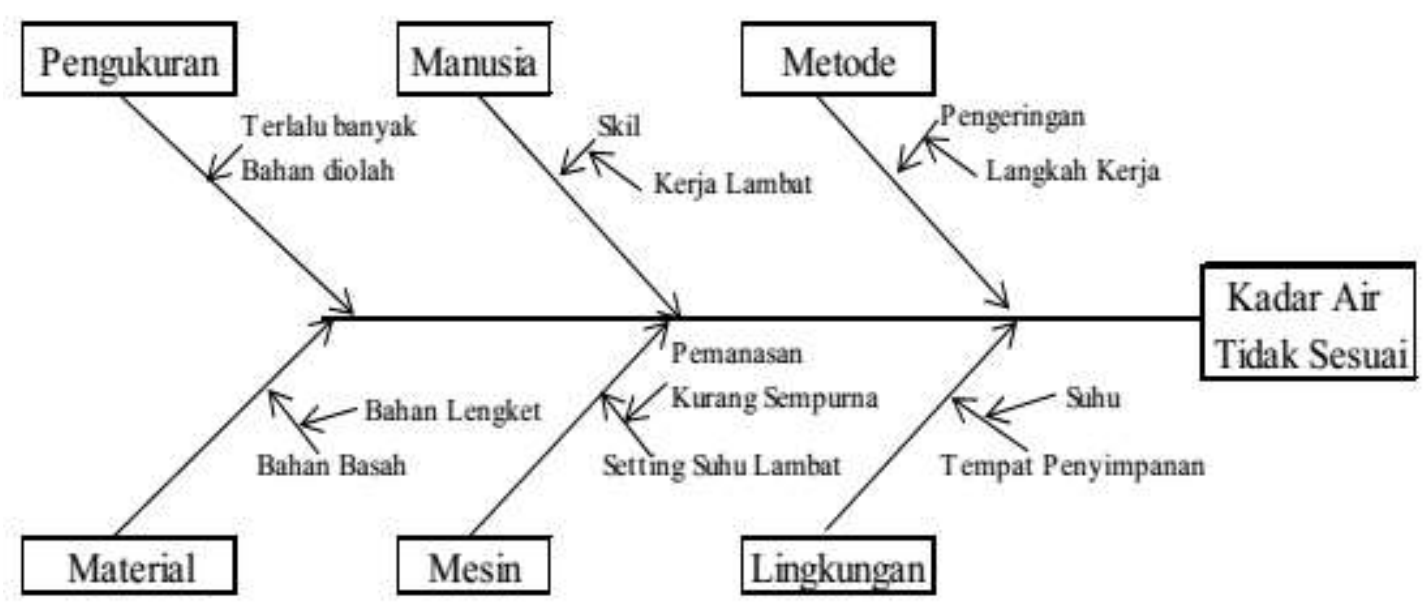

Kadar Air yang tidak sesuai dapat disebabkan oleh faktor-faktor di bawah ini yaitu:

\section{Faktor Metode}

Metode adalah cara atau prosedur yang dilakukan dalam suatu proses. Prosedur pengeringan bahan baku dilakukan menggunakan mesin oven dengan suhu 200 - 250 0C selama 1,5 jam. Oven yang digunakan adalah oven dengan instalasi gas yang diatur sedemikian rupa sehingga dapat memanaskan mesin oven. Terdapat lima buah mesin oven yang digunakan dalam proses pengeringan bahan baku. Operator yang bekerja di bagian ini harus terlatih dan memahami prosedur proses produksi, sehingga mampu untuk memantau bahan baku yang sedang dalam proses pengeringan. Operator harus mampu mengendalikan suhu di dalam oven dengan cara mengendalikan tekanan gas yang digunakan dalam proses pemanasan oven. Proses pengeringan bahan baku sangat penting dilakukan dengan prosedur yang benar karena mempengaruhi proses selanjutnya terutama pada gula yang dihasilkan. Selain suhu, waktu pemanasan juga sangat penting untuk dikontrol. Tidak semua bahan baku dioven selama 1,5 jam, hal ini dikarenakan perbedaan tingkat kekeringan dari bahan tersebut. Dalam hal ini kemampuan operator dalam menganalisa tingkat kekeringan bahan sangat berpengaruh pada lamanya waktu yang dibutuhkan dalam proses pengeringan. Untuk bahan baku yang kering waktu yang dibutuhkan hanya 1 jam saja sedangkan untuk bahan yang sedikit basah dibutuhkan waktu 1,5 jam agar didapatkan 
tingkat kekeringan yang sama. Dalam proses pengeringan bahan baku tidak boleh terjadi kesalahan karena sedikit kesalahan yang dilakukan akan sangat fatal akibatnya. Banyak masalah yang terjadi apabila prosedur tidak dijalankan dengan baik dan benar antara lain yaitu:

a. Suhu terlalu tinggi, suhu yang terlalu tinggi mengakibatkan gula menjadi kering dan terjadi over cooking sehingga kadar air menjadi rendah.

b. Suhu terlalu rendah, suhu yang terlalu rendah mengakibatkan gula tidak kering sehingga menghasilkan gula dengan kadar air yang tinggi.

\section{Faktor Manusia}

Faktor manusia merupakan faktor yang sangat penting karena manusia harus mampu mengendalikan peralatan dan mesin yang digunakan. Walaupun sekarang banyak mesin yang sudah menggunakan teknologi mutakhir akan tetapi hal itu akan menjadi tidak berguna jika kemampuan SDMnya tidak memadai. Sehingga mesin yang sudah canggihpun perlu ditunjang oleh operator yang mempunyai kemampuan dan pengetahuan yang cukup pada mesin yang dijalankannya. Kurangnya kemampuan dan skill operator dalam proses produksi mengakibatkan operator kurang memahami mesin dan akan menghambat pekerjaan. Dalam proses pengeringan kemampuan operator sangat dibutuhkan karena operator pada mesin oven gas harus mampu mengendalikan proses yang sedang berlangsung dan dapat melakukan perbaikan jika terjadi ketidaksesuaian pada mesin yang diakibatkan mesin yang rusak ataupun karena human error. Operator mesin oven sebaiknya perlu ditraining terlebih dahulu agar tidak banyak terjadi human error pada saat pengoperasian mesin oven. Mesin oven bukan mesin yang rumit akan tetapi kemampuan operator sangat berpengaruh pada saat pengoperasian mesin. Operator yang mempunyai kemampuan yang kurang akan mengakibatkan banyak sesalahan misalnya, operator tidak mampu mengatur tekanan gas yang dibutuhkan sehingga suhu yang diharapkan tidak tercapai. Hal ini harus dihindari sehingga operator harus benar-benar mampu menguasai mesin yang digunakan.

3. faktor Lingkungan

Faktor lingkungan merupakan faktor yang paling sulit untuk dikendalikan akan tetapi sulit bukan berarti tidak bisa dikendalikan. Pada saat pengiriman bahan baku dari supplier sebaiknya menggunakan kendaraan yang tertutup sehingga jika terjadi hujan pada saat proses pengiriman tidak akan berpengaruh pada bahan baku yang dikirim. Karena bahan baku gula semut sangat mudah menyerap air, maka lingkungan tempat penyimpanan harus selalu dijaga kelembabannya. Sebaiknya bahan baku disimpan ditempat yang menggunakan pendingin ruangan. Dengan adanya pendingin ruangan maka suhu dan kelembaban dapat diatur sehingga kualitas bahan baku dapat terjaga walaupun sudah disimpan cukup lama. Pendingin udara juga sangat dibutuhkan diruang ayak, karena diruang ayak bahan yang sudah diproses mengalami kontak langsung dengan udara sehingga udara yang ada sangat berpengaruh pada kadar air dari gula yang dihasilkan. Kontrol terhadap lingkungan akan berpengaruh pada gula yang dihasilkan, sehingga untuk menjaga kualitas gula yang dihasilkan lingkungan harus diatur menyesuaikan dengan bahan baku yang digunakan.

\section{Faktor Mesin}

Mesin merupakan faktor keempat yang harus disesuaikan dengan proses produksi gula semut. Mesin sangat berpengaruh terhadap kadar air terutama mesin oven yang digunakan. Mesin oven sebaiknya terdapat indikator suhu dan dilengkapi kaca untuk melihat isi di dalam oven tersebut. Indikator suhu digunakan untuk mengontrol tekanan gas yang digunakan agar suhu yang dinginkan tetap tercapai. Sedangkan kaca digunakan untuk memantau bahan yang sedang dioven 
sehingga tidak akan terjadi over cooking. Mesin oven sebaiknya dilakukan kalibrasi agar suhu yang tertera pada indikator suhu benar-benar merupakan suhu actual yang dicapai oleh mesin. Suhu optimal yang digunakan untuk pengeringan bahan baku sebesar 200 - 250oC. Jika suhu yang digunakan kurang dari $200 \mathrm{oC}$ maka bahan tidak kering dan akan sulit dilakukan penggilingan karena bahan akan lengket di mesin. Jika suhu yang digunakan melebihi $250 \mathrm{oC}$ akan terjadi kegosongan pada bahan. Setelah menggunakan mesin oven proses selanjutnya menggunakan mesin giling. Penggilingan dengan menggunakan kawat mesh 16 agar mudah dalam proses pengayakan. Mesin giling berpengaruh pada besar kecilnya partikel gula yang dihasilkan meskipun setelah penggilingan masih ada proses pengayakan. Pengayakan dilakukan dengan mesh 18 yang menjadi standar dari perusahaan. Bahan yang tidak lolos proses ayak akan kembali digiling sampai semua bahan bisa diayak.

\section{Faktor Material}

Bahan baku yang digunakan harus memenuhi standar yang ditetapkan perusahaan. Salah satu kontrol utama dari bahan baku adalah kadar air. Karena kadar air bahan baku sangat berpengaruh pada gula yang dihasilkan maka untuk mendapatkan gula dengan kadar air yang rendah maka bahan baku yang digunakan harus mempunyai kadar air yang rendah juga. Bahan baku yang memiliki kadar air yang tinggi akan cepat lengket dan membutuhkan waktu yang lama untuk proses pengeringan. Pemilihan bahan baku harus dilakukan agar pada saat proses pengeringan bahan bahan baku yang mempunyai kadar air tinggi bisa dicampur dengan bahan yang mempunyai kadar air rendah sehingga didapatkan bahan yang mempunyai kadar air yang seragam. Pemilihan supplier sangat penting untuk menjaga kualitas bahan baku yang digunakan. 6) Faktor Pengukuran Faktor pengukuran disini dititikberatkan pada saat proses pengeringan. Mesin oven yang digunakan mempunyai kapasitas tampung sebanyak $25 \mathrm{~kg}$. Apabila pada mesin dimasukkan bahan melebihi kapasitas maka bahan yang dioven akan lama keringnya sebaliknya jika bahan yang masuk ke dalam oven kurang dari $25 \mathrm{~kg}$ maka bahan menjadi cepat gosong, kadar air rendah dan akan terjadi rasa pahit pada gula yang dihasilkan. Pengukuran jumlah gula pada saat pengeringan sangat menentukan kadar air dan jumlah gula yang dihasilkan. Untuk mendapatkan kadar air yang sesuai dengan hasil yang sesuai pula, maka bahan yang dimasukkan dalam oven harus sesuai dengan kapasitas mesin oven tersebut.

\section{E. Usulan Tindakan Perbaikan}

Dari analisa pengendalian statistik yang dilakukan terhadap kecacatan produk di CV. Dwi Sarana Mandiri dapat diketahui bahwa pengaruh kadar air sangat berpengaruh besar terhadap kecacatan palm sugar. kadar air yang tinggi menyebabkan palm sugar membeku sedangkan kadar air yang rendah menyebabkan palm sugar menjadi basah dan lengket. Dalam penelitian ini penulis melakukan analisa beberapa perbaikan dengan melakukan perbaikan kualitas terhadap kecacatan produk yang disebabkan kadar air, ukuran partikel dan kebersihan. Perbaikan - perbaikan yang dilakukan adalah sebagai berikut:

1. Kecacatan karena kadar air tinggi bisa diakibatkan karena bahan baku yang digunakan mempunyai kadar air yang melebihi batas toleransi yaitu melebihi 5 $6 \%$, untuk mengatasi hal ini bisa dilakukan dengan penyortiran bahan baku yang digunakan agar hasil yang didapatkan sesuai. Penyortiran dilakukan dengan memisahkan bagian-bagian dari bahan baku yang meleleh dan lengket, untuk selanjutnya dilakukan perbaikan terhadap bahan baku yang meleleh dengan cara menjemur di bawah panas matahari. Selain itu juga bisa dilakukan dengan melakukan perbaikan proses pada saat pengeringan. Misalnya untuk bahan yang basah bisa ditambah waktu pada proses pengeringannya. 
2. Penyimpanan bahan baku juga akan mempengaruhi kadar air pada gula yang dihasilkan. Perbaikan pada saat penyimpanan perlu dilakukan dengan cara membuat tempat penyimpanan yang mempunyai alat untuk pengatur udara (Air Conditioner), sehingga suhu udara dan kelembaban dapat diatur agar bahan baku tidak banyak menyerap air dari udara yang menyebabkan kadar air bahan baku menjadi tinggi dan lengket.

3. Pada proses pengayakan sebaiknya dilakukan di tempat yang memiliki alat pengatur udara agar pada saat bahan berada pada mesin ayak udara tidak mempengaruhi kadar airnya, suhu di ruangan ini harus mencapai $20-250 \mathrm{C}$, sesuai standar pada peraturan mentri nomor 1405/MENKES/SK/XI/2002.

4. Kadar air yang rendah karena terjadi over cooking pada saat proses pengeringan, langkah perbaikan yang harus dilakukan adalah dengan mengontrol suhu pada saat pengeringan yang disesuaikan dengan tingkat kekeringan bahan baku yang dioven yaitu berkisar antara 200 - 2500C sesuai dengan standar yang telah ditetapkan oleh manajemen kualitas CV. Dwi Sarana Mandiri. Hal ini untuk menghindari over cooking sehingga kadar air tidak rendah dan masuk dalam spesifikasi yang diinginkan yaitu $2-2,3 \%$.

5. Jika kecacatan produk disebabkan oleh kadar air yang rendah, maka langkah yang akan dilakukan adalah dengan mencampurkan kembali produk yang memiliki kadar air rendah dengan produk yang memiliki kadar air tinggi, dengan ratio $50: 50$, hal ini telah diteliti dalam penelitian ini yang menjadikan perbaikan terhadap produk yang memiliki kadar air tinggi bila dicampurkan dengan kadar air yang rendah maka penampakan dan bentuk produk akan baik dengan kadar air yang sesuai pula.

6. Ukuran partikel yang tidak sesuai dapat dilakukan perbaikan dengan menyamakan ukuran kawat saringan mesin giling dengan ukuran kawat mesin ayakan hingga semua bahan lolos tanpa sisa, karena sisasisa yang terdapat pada proses pengayakan ini akan menimbulkan pemborosan pada proses produksi dan pemborosan pada tenaga dan waktu produksi.

7. Kebersihan dapat dilakukan dengan memisahkan kotoran dengan cara penyortiran oleh salah seorang operator produksi, dalam hal ini operator diberikan pemahaman kotoran seperti apa saja yang harus dipisahkan, kotoran-kotoran disini berupa ijuk dari pohon aren, serpihan kayu pohon aren, potongan kelapa, tali plastik dan kotoran-kotoran lain yang mencemarinya.

\section{KESIMPULAN}

Dari penelitian yang dilakukan di CV. Dwi Sarana Mandiri kesimpulan yang didapat adalah:

1. Pengaruh kadar air dalam pengendalian kualitas palm sugar di CV. Dwi Sarana Mandiri sangat besar hal ini dapat dilihat dari persentase kerusakan yang terjadi pada bulan Mei 2012 - Oktober 2012 mencapai angka 12,15\%. Sehingga kadar air menjadi faktor utama dalam pengendalian kualitas di CV. Dwi Sarana Mandiri. Untuk mengurangi kerusakaan tersebut bisa dilakukan dengan memperbaiki metoda dan penyimpanan bahan baku, mengendalikan proses pengeringan, dan juga proses pengayakan dilakukan diruangan yang memiliki alat pengatur udara.

2. Pelaksanaan pengendalian kualitas pada CV. Dwi Sarana Mandiri belum mencapai batas kendali yang ditentukan karena dari hasil diagram kontrol,masih banyak kecacatan produk yang terjadi hingga berada jauh di atas batas kendali atas yang telah ditentukan. Dari diagram control dapat dilihat masih banyak produk yang berada diluar batas kendali sehingga produk yang dihasilkan banyak yang mengalami kerusakan terutama karena 
kadar air. Kadar air merupakan kendali kualitas utama dalam proses pembuatan gula semut.

3. Pengendalian kualitas yang dilakukan di CV. Dwi Sarana Mandiri yaitu dengan cara pemeriksaan mulai dari penerimaan bahan baku gula sampai produk jadi, bahan baku yang diterima dan produk jadi akan selalu di kontrol dan dipastikan kadar airnya sesuai dengan standar yang telah ditetapkan. Selain itu kebersihan dari bahan baku gula juga sangat diperhatikan. Karena pengolahan nira aren yang diolah langsung oleh petani-petani aren sangat memungkinkan adanya kotorankotoran lain yang ikut serta seperti contohnya serat kulit pohon aren, arang dari api pembakaran, ijuk dan lain sebagainya

\section{DAFTAR PUSTAKA}

Buffa, Elwood S. Sarin, Rakesh K, 1996. Manajemen Operasi \& Produksi Moder,. Edisi Kedelapan, Jilid I, Jakarta : Binarupa Aksara

Fandy Tjiptono, Gregorius Chandra, 2011. Service, Quality \& Satisfaction, Jakarta: Andi.

Fandy Tjiptono, 2004. Total Quality Manajement (TQM), Jakarta : Andi

Gaspersz, Vincent, Total Quality Management (TQM), Jakarta: PT.Gramedia Pustaka Utama.
Herjanto, Eddy, Manajemen Operasi, Jakarta: Grasindo. Ibrahim, Buddy, 2000. TQM (Total Quality Management): Panduan Menghadapi Persaingan Global, Jakarta: Djambatan

Juran, J.M., 1995. Kepemimpinan Mutu, Jakarta: Pustaka Binaman Pressindo.

Leavenworth, Richard S, 1994. Pengendalian Mutu Statistis, Jakarta: Erlangga.

Nasution, M. N, Manajemen Mutu Terpadu (Total Quality Management), Jakarta: Ghalia Indonesia.

Nasution, A.H.,2006. Manajemen Industri. Yogyakarta: Penerbit Andi.

Prawirosentono, Suyadi, Filosofi Baru Tentang Manajemen Mutu Terpadu Abad 21 (Kiat Membangun Bisnis Kompetitif), Jakarta: Bumi Aksara.

Purnomo, Dwi, Manajemen Mutu Terpadu, BAB 3. Manajemen Mutu Terpadu Kul.pdf-ebook, FTIP-UNPAD, diunduh 2/09/2012.

Render, Barry., dan Jay Heizer, 2001. Prinsipprinsip Manajemen Operasi, Jakarta: Salemba Empat www.gizikia.depkes.go.id 